\title{
PENGARUH GAYA KEPEMIMPINAN TERHADAP KINERJA PEGAWAI PADA DINAS PENDIDIKAN DAN KEBUDAYAAN KOTA MAKASSAR
}

\author{
Ardiansyah Halim \\ Sekolah Tinggi Ilmu Ekonomi Makassar (STIEM) Bongaya \\ ardiansyahhalim@stiem-bongaya.ac.id
}

\begin{abstract}
ABSTRAK
Tujuan dari penelitian ini adalah untuk mengetahui dan menganalisis pengaruh gaya kepemimpinan (X) yang terdiri dari kepemimpinan supportive (X1), kepemimpinan directive (X2), kepemimpinan partisipative (X3) baik secara simultan maupun parsial terhadap kinerja pegawai (Y) pada Dinas Pendidikan dan Kebudayaan Kota Makassar. Jenis penelitian ini adalah penelitian deskriptif kuantitatif. Sifat penelitian ini adalah penelitian explanatory. Populasi dalam penelitian ini adalah pegawai Dinas Pendidikan dan Kebudayaan Kota Makassar yang berjumlah 58 orang berstatus PNS. Adapun alasannya karena jumlah PNS yang sedikit jadi seluruh populasi dijadikan sampel dalam penelitian ini (sensus). Teknik pengumpulan data dalam penelitian ini dilakukan melalui wawancara, kuesioner, dan studi dokumentasi.Hasil penelitian bahwa secara simultan terdapat pengaruh positif dan signifikan gaya kepemimpinan terhadap kinerja pegawai. Secara parsial variabel gaya kepemimpinan suportif $\left(\mathrm{X}_{1}\right)$ dan partisipatif $\left(\mathrm{X}_{3}\right)$ berpengaruh positif dan signifikan terhadap kinerja pegawai, sedangkan gaya kepemimpinan direktif $\left(\mathrm{X}_{2}\right)$ berpengaruh tidak signifikan terhadap kinerja pegawai pada Dinas Pendidikan dan Kebudayaan Kota Makassar. Berdasarkan hasil penelitian ini, diharap pimpinan dapat lebih tegas pada bawahan dalam hal ini pegawai untuk mengikuti peraturan-peraturan dan mengkoordinasi pekerjaan mereka dengan baik, sehingga kinerja pegawai yang selama ini rendah dan kemampuan pegawai dalam memahami tupoksinya dalam pelaksanaan program diharapkan dapat tercapai.

Kata Kunci: Kepemimpinan Suportif; Direktif; Partisipatif; Kinerja Pegawai
\end{abstract}

\begin{abstract}
The purpose of this study was to determine and analyze the influence of leadership style (X) consisting of supportive leadership (X1), directive leadership (X2), participative leadership (X3) both simultaneously and partially on employee performance $(Y)$ at Departement of Education and Culture of Makassar City. This type of research is a quantitative descriptive study. The nature of this research is explanatory research. The population in this study were employees on the Departement of Education and Culture of Makassar City, totaling 58 civil servants. The reason was that the number of civil servants was small so the entire population was sampled in this study (census). Data collection techniques in this study were carried out through interviews, questionnaires, and documentation studies. The results showed that simultaneously there is a positive and significant influence of leadership style on employee performance. Partially supportive (X1) and participatory (X3) leadership style variables have a positive and significant effect on employee performance, while directive leadership style (X2) has no significant effect on Departement of Education and Culture of Makassar City. Based on the results of this study, it is hoped that the leadership can be more assertive in subordinates, in this case employees, to follow the regulations and coordinate their work well, so that the employee's performance which has been low and the ability of employees to understand their duties in implementing the program is expected to be achieved.

Keywords: Supportive Leadership; Directive; Participative; Employee Performance
\end{abstract}




\section{PENDAHULUAN}

Setiap perusahaan memiliki tujuan yang ingin dicapai, dalam usaha pencapaian tujuan tersebut perusahaan sangat berperan penting dalam mengelola, mengatur, dan menggunakan sumber daya manusia agar perusahaan dapat bekerja secara produktif, efektif dan efisien. Masalah kinerja tidak terlepas dari proses, hasil dan daya guna, dalam hal ini kinerja atau prestasi kerja merupakan hasil kerja secara kualitas dan kuantitas yang dicapai oleh seorang pegawai dalam melaksanakan tugasnya sesuai dengan tanggung jawab yang diberikan kepadanya. Kinerja didefinisikan sebagai pencapaian hasil atau tingkat pencapaian tingkat organisasi, kinerja pegawai yang baik secara langsung mempengaruhi kinerja organisasi.

Penilaian terhadap kinerja dapat dilakukan secara terarah dan sistematis. Dengan adanya informasi mengenai kinerja maka dengan mudah dapat dilakukan dan mendorong untuk memperbaiki kinerja. Kinerja karyawan adalah yang memengaruhi seberapa banyak mereka memberi kontribusi kepada organisasi antara lain termasuk kuantitas output, kualitas output, jangka waktu output, kehadiran di tempat kerja dan sikap koperatif (Mathis \& Jackson, 2011). Arifin (2014) dalam (Dunggio, 2020) juga mengatakan bahwa kinerja karyawan ditentukan oleh kepemimpinan dan budaya organisasi. Kepemimpinan dan pengaruhnya terhadap perusahaan dan karyawan adalah topik yang menarik. Gaya kepemimpinan seperti transaksional, suportif, partisipatif, kepemimpinan spiritual, kepemimpinan kewirausahaan (Zehir et al., 2011). Gaya kepemimpinan (Yukl, 1998) dalam (Jumady, 2020b) terdiri dari kepemimpinan supportive, kepemimpinan directive, dan kepemimpinan partisipative.

Kemampuan dan keterampilan dari seorang pimpinan adalah faktor penting dalam memotivasi pegawainya agar bekerja dengan baik. Dalam hal ini pengaruh seorang pemimpin sangat menentukan arah tujuan dari organisasi (Tueno, 2016). Rezeki (2010) dalam (Jumady, 2020) telah meneliti pengaruh gaya kepemimpinan terhadap kinerja karyawan, menyatakan bahwa gaya kepemimpinan mempunyai pengaruh yang signifikan terhadap kinerja karyawan. Kepemimpinan merubah suatu yang potensial menjadi suatu kenyataan dan ini merupakan kegiatan pokok yang memberikan kesuksesan bagi organisasi (Rapanna \& Jumady, 2020). Oleh karena itu arti penting kepemimpinan tercermin sebagai suatu fungsi yang memiliki nilai potensial baik secara individu maupun organisasi dalam pencapaian tujuan. (Handayani, 2017). Pemimpin yang mampu untuk dapat mengarahkan bawahannya dengan baik agar membuat bawahannya dapat melakukan pekerjaan dengan baik sehingga dapat meningkatkan kinerja 
dan juga apabila pemimpin dalam gaya kepemimpinannya disukai oleh pegawainya akan menyebabkan pegawai tersebut merasa puas dalam bekerja.

Dinas Pendidikan dan

Kebudayaan Kota Makassar merupakan unsur pelaksana otonomi daerah di bidang pendidikan yang mempunyai tugas pokok membantu pemerintah daerah dalam melaksanakan sebagian kewenangan daerah di bidang pendidikan dan kebudayaan. Berdasarkan UU Nomor 23 Tahun 2104 tentang Pemerintah Daerah, bahwa untuk penyelenggaraan pemeritahan daerah, kepala daerah perlu dibantu oleh perangkat daerah yang dapat menyelenggarakan seluruh urusan pemerintahan yang dilaksanakan oleh pemerintah daerah (Dunggio, 2020).

Berdasarkan pengamatan penulis mengenai permasalahan kinerja pegawai dapat dilihat dari masih adanya pegawai yang keluar kantor di waktu jam kerja untuk kepentingan pribadi, ada beberapa pegawai yang masuk kerja siang dan pulangnya awal dari ketentuan jam masuk kerja dan jam pulang kerja hal ini disebabkan tidak adanya peringatan maupun tindakan tegas yang dilakukan oleh pimpinan terhadap pelanggaran tersebut hal ini juga menyebabkan pegawai yang rajin menjadi tidak termotivasi untuk tetap mengikuti pedoman normatif yang berlaku.

Kepemimpinan pada Dinas

Pendidikan dan Kebudayaan Kota Makassar yang berlangsung selama ini juga mendapat keluhan dari para pegawai seperti kurangnya pengawasan terhadap pegawai dalam setiap tindakannya pada saat bertugas. Pimpinan hanya melibatkan pegawai tertentu dalam setiap kebijakan yang dibuatnya sehingga pegawai yang lain merasa tidak berperan. Selain itu, kurangnya komunikasi dari pimpinan mengenai mekanisme kerja sehingga pegawai melaksanakan pekerjaan sesuai dengan persepsinya sendiri.Rendahnya kinerja pegawai juga dilihat dari kemampuan pegawai dalam memahami tupoksinya dan pelaksanaan program sehingga kinerja yang diharapkan sulit untuk tercapai.

Tujuan dari penelitian ini adalah untuk mengetahui dan menganalisis pengaruh gaya kepemimpinan (X) yang terdiri dari kepemimpinan supportive (X1), kepemimpinan directive (X2), kepemimpinan partisipative (X3) baik secara simultan maupun parsial terhadap kinerja pegawai (Y) pada Dinas Pendidikan dan Kebudayaan Kota Makassar.

\section{PERMASALAHAN}

Adapun rumusan dalam penelitian ini adalah bagaimana pengaruh gaya kepemimpinan yang terdiri dari kepemimpinan suportif, direktif, dan partisipatif terhadap kinerja pegawai Kantor Dinas Pendidikan dan Kebudayaan Kota Makassar?

\section{Tujuan penelitian}

Berdasarkan rumusan masalah tersebut di atas, maka tujuan penelitian ini adalah untuk mengetahui dan menganalisis pengaruh gaya kepemimpinan yang terdiri dari kepemimpinan suportif, direktif, dan 
partisipatif terhadap kinerja pegawai Kantor Dinas Pendidikan dan Kebudayaan Kota Makassar.

\section{Fokus Penelitian}

Berdasarkan latar belakang yang telah diuraikan tersebut diatas, maka fokus penelitian sebagai berikut:

\section{Kepemimpinan Suportif}

Yang dimaksud dengan kepemimpinan suportif adalah memberi perhatian kepada bawahan dan menciptakan suasana yang bersahabat

\section{Kepemimpinan Direktif}

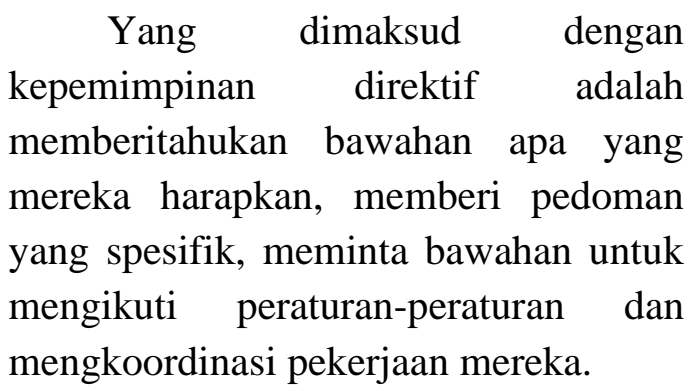

\section{Kepemimpinan Partisipatif}

Yang dimaksud dengan kepemimpinan partisipatif adalah gaya pimpinan berkonsultasi dengan para bawahan dan memperhitungkan opini dan saran mereka.

\section{METODE PENELITIAN}

Jenis penelitian ini adalah penelitian deskriptif kuantitatif. Sifat penelitian ini adalah penelitian explanatory. Penelitian explanatory merupakan penelitian yang bermaksud menjelaskan kedudukan variabelvariabel yang diteliti serta hubungan antara satu variabel dengan yang lainnya (Sugiono, 2010).

\section{Populasi dan Sampel}

Populasi dalam penelitian ini adalah pegawai Dinas Pendidikan dan Kebudayaan Kota Makassar yang berjumlah 58 orang berstatus PNS sedangkan teknik penarikan sampel menggunakan sampel jenuh adapun alasannya karena jumlah PNS yang sedikit jadi seluruh populasi dijadikan sampel sebanyak 58 responden.

\section{Teknik Pengumpulan Data}

Teknik pengumpulan data dalam penelitian ini dilakukan melalui wawancara, kuesioner, dan studi dokumentasi. Teknik pengumpulan data yang digunakan dalam penelitian ini:

1. Wawancara yaitu pengumpulan data dengan cara pengamatan langsung pada objek yang diteliti, atau dapat dirumuskan sebagai proses pencatatan pola perilaku subyek (orang), objek (benda) atau kejadian sistematik tanpa adanya pertanyaan atau komunikasi dengan individu yang diteliti.

2. Angket/Kuesioner yaitu teknik pengumpulan data yang digunakan dengan cara menyebarkan daftar pertanyaan kepada responden penelitian. Setiap jawaban pertanyaan diberikan skor sesuai dengan masingmasing skala pengukuran.

\section{Metode Analisis}

Metode analisis yang digunakan adalah regresi linear berganda. Menurut (Sugiono, 2010), regresi linear berganda yaitu menguji pengaruh dua atau lebih 
variabel independen terhadap satu variabel dependen. Analisis regresi bertujuan untuk untuk mengetahui apakah regresi yang dihasilkan adalah baik untuk mengestimasikan nilai variabel dependen. Analisis ini bertujuan untuk mengetahui pengaruh variabel bebas terhadap variabel terikat yaitu gaya kepemimpinan suportif, kepemimpinan direktif dan kepemimpinan partisipatif terhadap kinerja pegawai pada Dinas Pendidikan Dan Kebudayaan Kota Makassar.Adapun rumus regresi linear berganda yang digunakan adalah sebagi berikut:

$$
Y=a+b_{1} X_{1}+b_{2} X_{2}+b_{3} X_{3}+e i
$$

\section{HASIL PENELITIAN DAN PEMBAHASAN}

Uji validitas daftar pertanyaan untuk mengukur sah atau valid tidaknya suatu kuesioner. Suatu kuesioner dikatakan valid jika pertanyaan pada kuesioner mampu menganggap sesuatu yang diukur oleh kuesioner tersebut adalah dengan menggunakan metode corrected item-total correlation yaitu dilakukan dengan cara mengkorelasikan masing-masing score item dengan scor total dan melakukan korelasi terhadap nilai koefisien korelasi yang over estimate. 
Tabel 1: Hasil Uji Validitas Gaya Kepemimpinan dan Kinerja Karyawan

\begin{tabular}{|c|c|c|c|}
\hline Kode Pertanyaan & $\begin{array}{c}\text { Corrected Item } \\
\text { Total Correlation }\end{array}$ & Rstandar & Kesimpulan \\
\hline Item_1 & 0,622 & & \\
\hline Item_2 & 0,632 & & \\
\hline Item_3 & 0,546 & & \multirow{2}{*}{$\mathbf{0}, 30$} \\
\hline Item_4 & 0,690 & & Valid \\
\hline Item_5 & 0,565 & & \\
\hline Item_6 & 0,704 & & \\
\hline Item_7 & 0,652 & \\
\hline Item_8 & 0,588 & \\
\hline Item_9 & 0,501 & \\
\hline Item_10 & 0,688 & & \\
\hline Item_11 & 0,604 & & \\
\hline Item_12 & 0,624 & & \\
\hline Sun_. & & & \\
\hline
\end{tabular}

Sumber: Data diolah, 2020

Berdasarkan hasil uji validitas atas variabel gaya kepemimpinandan kinerja pegawai dengan 12 item pernyataan yang diajukan, maka terlihat bahwa semua pernyataan tersebut sudah valid atau sah karena memiliki nilai corrected item total di atas dari 0,30 .

Tabel 2: Hasil Uji Reliabilitas

\begin{tabular}{|l|c|c|c|}
\hline \multicolumn{1}{|c|}{ Variabel Penelitian } & $\begin{array}{c}\text { Cronbach's } \\
\text { Alpha }\end{array}$ & Rstandar & Keterangan \\
\hline Kepemimpinan Suportif (X1) & 0,716 & \multirow{2}{*}{0,60} & Reliabel \\
Kepemimpinan Direktif (X2) & 0,692 & & \\
Kepemimpinan Partisipatif (X3) & 0,826 & & \\
Kinerja Pegawai (Y) & 0,844 & & \\
\hline
\end{tabular}

Sumber: Data diolah, 2020

Dari tabel 2 diatas yakni hasil uji reliabilitas atas variabel gaya kepemimpinan dan kinerja karyawan pada kantor Dinas pendidikan dan Kebudayaan kota Makassar menunjukkan semua item pertanyaan semuanya reliabel sebab memiliki nilai cronbach's alpha $(\alpha)$ di atas 0,60 . 


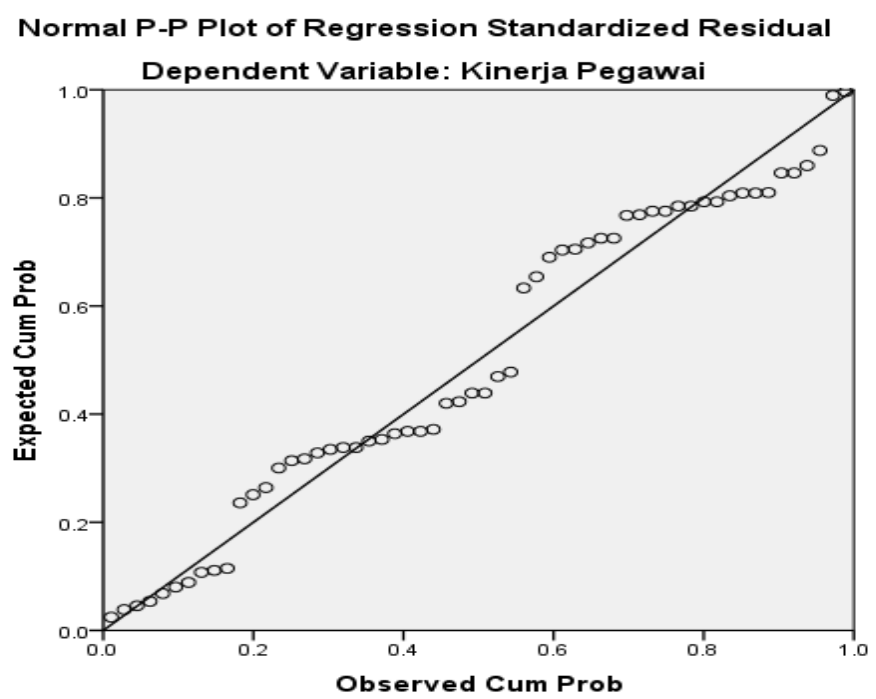

Gambar 1. Uji Normalitas

Berdasarkan tampilan grafik Normal P-Plot diatas, dapat disimpulkan bahwa pola grafik normal terlihat dari titik-titik yang menyebar disekitar garis diagonal dan penyebarannya mengikuti arah garis diagonal. Berdasarkan grafik normal plot, menunjukkan bahwa model regresi layak dipakai dalam penelitian ini karena memenuhi asumsi normalitas.

Pengujian hipotesis menyatakan bahwa kepemimpinan suportif $\left(\mathrm{X}_{1}\right)$, kepemimpinan direktif $\left(\mathrm{X}_{2}\right)$ dan kepemimpinan partisipatif $\left(\mathrm{X}_{3}\right)$ secara simultan dan parsial berpengaruh positif dan signifikan terhadap kinerja pegawai $(\mathrm{Y})$ pada Dinas Pendidikan Dan Kebudayaan Kota Makassar.

Tabel 3. Hasil Koefisien Regresi

\begin{tabular}{|c|c|c|c|c|c|c|}
\hline \multirow{2}{*}{\multicolumn{2}{|c|}{ Model }} & \multicolumn{2}{|c|}{ Unstandardized Coefficients } & \multirow{2}{*}{\begin{tabular}{|l|l} 
Standardized \\
Coefficients
\end{tabular}} & \multirow[t]{2}{*}{$\mathrm{t}$} & \multirow[t]{2}{*}{ Sig. } \\
\hline & & B & Std. Error & & & \\
\hline \multirow{4}{*}{1} & (Constant) & .059 & 8.000 & & .007 & .994 \\
\hline & Suportif & .570 & .155 & .360 & 3.687 & .001 \\
\hline & Direktif & .150 & .134 & .104 & 1.117 & .269 \\
\hline & Partisipatif & .528 & .095 & .515 & 5.538 & .000 \\
\hline
\end{tabular}

a. Dependent Variable: Kinerja Pegawai

Sumber: Data primer (kuisioner) diolah (2020)

Hasil koefisien Regresi dapat diperoleh hasil persamaan regresi untuk penelitian ini adalah sebagai berikut:

$$
Y=0,059+0,570 X_{1}+0,150 X_{2}+0,528 X_{3}
$$


Dari persamaan tersebut dapat digambarkan sebagai berikut: konstanta (a) $=0,059$, di mana jika nilai variabel Independen diasumsikan dengan nol, maka diperoleh nilai kinerja pegawai $(Y)=0,059$. Koefisien $X_{1}\left(\beta_{1}\right)=0,570$, menunjukkan bahwa variabel kepemimpinan suportif $\left(\mathrm{X}_{1}\right)$ berpengaruh positif terhadap kinerja pegawai (Y), dengan kata lain jika variabel kepemimpinan suportif ditingkatkan sebesar satu satuan maka kinerja pegawai bertambah sebesar 0,570 . Hal ini juga menunjukkan bahwa kepemimpinan suportif searah dengan kinerja pegawai, bila kepemimpinan suportif meningkat berdampak positif terhadap meningkatnya kinerja pegawai.

Koefisien $\mathrm{X}_{2} \quad\left(\beta_{2}\right)=0,150$, menunjukkan bahwa kepemimpinan direktif $\left(\mathrm{X}_{2}\right)$ berpengaruh positif terhadap kinerja pegawai (Y), jika variabel kepemimpinan direktif ditingkatkan sebesar satu satuan maka kinerja pegawai bertambah sebesar 0,150 . Hal ini juga menunjukkan bahwa kepemimpinan direktif searah dengan kinerja pegawai. Koefisien $X_{3}\left(\beta_{3}\right)=$ 0,528, menunjukkan bahwa kepemimpinan partisipatif $\left(\mathrm{X}_{3}\right)$ berpengaruh positif terhadap kinerja pegawai (Y), jika variabel kepemimpinan partisipatif ditingkatkan sebesar satu satuan maka kinerja pegawai bertambah sebesar 0,528. Hal ini juga menunjukkan bahwa kepemimpinan partisipatif searah dengan kinerja pegawai, bila kepemimpinan partisipatif meningkat berdampak positif terhadap meningkatnya kinerja pegawai.

Hasil temuan dalam penelitian ini bahwa nilai $\mathrm{R}$ menjelaskan mengenai tipe hubungan antar variabel, semakin besar nilai $\mathrm{R}$ berarti hubungan semakin erat. Nilai $\mathrm{R}$ sebesar 0,771 berarti hubungan (relation) antara kepemimpinan suportif, direktif, dan partisipatif terhadap kinerja pegawai pada Dinas Pendidikan Dan Kebudayaan Kota Makassar sebesar $77,1 \%$, artinya ada hubungan yang kuat. Koefisien korelasi yang diteliti berada di interval koefisien $0,600-0,799$ tingkat hubungannya kuat (Sugiyono, 2012)

Diketahui nilai koefisien determinasi $\quad\left(\mathrm{R}^{2}\right) \quad$ sebesar $\quad 0,594$ menunjukan bahwa gaya kepemimpinan suportif, direktif, dan partisipatif sebagai variabel independent, mampu menjelaskan kinerja pegawai pada Dinas Pendidikan Dan Kebudayaan Kota Makassar sebagai variabel dependent sebesar 59,4\% sedangkan sisanya sebesar $40,6 \%$ dijelaskan oleh faktor-faktor lain yang tidak dimasukkan ke dalam model penelitian misalnya: lingkungan kerja, kompetensi dan kepuasan kerja.

Berdasarkan hasil penelitian
menunjukkan adanya pengaruh
positifdan signifikan kepemimpinan
suportif $\left(\mathrm{X}_{1}\right)$ terhadap kinerja pegawai
(Y) sebesar 0,360 atau $36.00 \%$ dengan
nial signifikan sebesar 0,001 . Hal ini


menunjukkan bahwa semakin baiknya gaya kepemimpinan suportif akan berdampak padameningkatnya kinerja pegawai.

Berdasarkan hasil penelitian menunjukkan adanya pengaruh positifdan tidak signifikan kepemimpinan direktif $\left(\mathrm{X}_{2}\right)$ terhadap kinerja pegawai (Y) sebesar 0,104 atau $10,40 \%$ dengan nial signifikan sebesar 0,269 . Hal ini menunjukkan bahwa semakin baiknya gaya kepemimpinan direktif akan berdampak pada meningkatnya kinerja pegawai.

Berdasarkan hasil penelitian menunjukkan adanya pengaruh positif dan signifikan kepemimpinan partisipatif $\left(\mathrm{X}_{3}\right)$ terhadap kinerja pegawai (Y) sebesar 0,515 atau $51,50 \%$ dengan nial signifikan sebesar 0,000 . Hal ini menunjukkan bahwa semakin baiknya gaya kepemimpinan partisipatif akan berdampak pada meningkatnya kinerja pegawai.

Pengaruh Gaya Kepemimpinan (X) yang tertiri dari Kepemimpinan Suportif $\left(\mathrm{X}_{1}\right), \quad$ direktif $\left(\mathrm{X}_{2}\right)$, partisipatif $\left(\mathbf{X}_{3}\right)$ Secara Simultan Terhadap Kinerja Pegawai (Y)

Uji $F$ dilakukan untuk menguji apakah kepemimpinan suportif, direktif, partisipatif secara simultan berpengaruh positif dan signifikan terhadap kinerja pegawai pada Dinas Pendidikan dan Kebudayaan Kota Makassar. Berdasarkan Uji Simultan (Uji F) bahwa Nilai $F_{\text {hitung }}=26,826$ dan $F_{\text {tabel }}=$
2,78, dalam hal ini jika $F_{\text {hitung }}>F_{\text {tabel }}$ dan nilai signifikan adalah 0.000 lebih kecil dari nilai alpha $\alpha=0.05$ sehingga keputusan yang diambil adalah $\mathrm{H}_{0}$ ditolak dan $\mathrm{H}_{1}$ diterima. Artinya kepemimpinan suportif, direktif, partisipatif secara simultan berpengaruh positif dan signifikan terhadap kinerja pegawai.Diterima.

Gaya kepemimpinan yang tepat menjadi hal penting dalam suatu organisasi. Seorang pemimpin yang baik tau bagaimana menerapkan perilaku-perilaku tertentu untuk memotivasi bawahan sehingga lebih termotivasi dalam bekerja dan mendorong mereka untuk lebih giat dan semangat serta dapat melakukan tugas dan tanggung jawabnya sesuai target yang telah ditentukan organisasi sehingga kinerja yang baik (Jannah \& Jumady, 2020). Hasil ini sesuai dengan fakta yang terjadi dilapangan melalui wawancara yang dilakukan oleh penulis terhadap beberapa responden menyatakan kemampuan pimpinan dalam hal ini kepala dinas memadukan gaya kepemimpinan yang berorientasi pada orang (hubungan) dan gaya kepemimpinan yang beroreitasi pada tugas sangat baik. Ini dibuktikan dengan terjalinnya hubungan yang baik antara bawahan dan atasan serta pemberian penghargaan kepada pegawai yang berprestasi juga adanya ruang yang diberikan kepala dinas dalam hal mengemukakan pendapat mengenai pekerjaan yang diperintahkan. 
Kepala Dinas Pendidikan Dan Kebudayaan Kota Makassar juga sering melakukan pantau langsung dalam hal pengawasan pekerjaan yang dilakukan oleh pegawai dan selain pemberian penghargaan yang berprestasi juga adanya ancaman atau hukuman bagi pegawai yang berprestasi buruk atau tidak dapat melaksanakan tugas-tugas yang telah ditentukan hal ini menurut beberapa responden Kepala Dinas sangat menjaga hubungan yang baik dengan pegawainya dengan adanya kegiatan-kegiatan yang sering dilakukan bersama-sama tapi sangat ketat dalam mengawasi pegawainya dalam hal target pekerjaan. Hal ini sesuai dengan penelitian (Putra et al., 2013), (Khairizah et al., 2015) bahwa gaya kepemimpinan baik kepemimpinan suportif, direktif maupun partisipatif berdampak positif terhadap meningkatnya kinerja pegawai. Gaya kepemimpinan ini sesuai dengan teori Path Goal sebagaimana dikutip (Robbins, 2015)

\section{Pengaruh Kepemimpinan Suportif (X1) Secara Parsial Terhadap Kinerja} Pegawai (Y)

Hasil olahan data diperoleh nilai $t_{\text {hitung }}$ untuk variabel kepemimpinan suportif 3,687 lebih besar dibandingkan dengan $t_{\text {tabel }} 1,674$ dan nilai signifikan sebesar 0,001 $(<0.05)$ artinya signifikan. Jadi terbukti bahwa kepemimpinan suportif secara parsial berpengaruh signifikan terhadap kinerja pegawai. Diterima.

Sesuai dengan teori kepemimpinan (Luthans, 2011) bahwa kepemimpinan Suportif yaitu gaya kepemimpinan yang selalu bersedia menjelaskan segala permasalahan pada bawahan, mudahdidekati dan memuaskan hati para karyawan. Pemimpin tipe ini biasanya menunjukan sikap yang ramah dan menunjukan kepedulian pada bawahaannya, mempertimbangkan kebutuhan daripara bawahan, menunjukkan perhatian mereka untuk menciptakan kesejahteraan dan ramah lingkungan kerja. Hasil penelitian ini sesuai pendapat Davis dan Newstrom (2006) dalam (Yulistian et al., 2013) bahwa pemimpin yang memusatkan kuasa dan pengambilan keputusan bagi dirinya sendiri, pemimpin menata situasi kerja yang rumit bagi para pegawai, yang melakukan apa saja yang diperintahkannya. Pemimpin berwenang penuh dan memikul tanggung jawab sepenuhnya.

\section{Pengaruh Kepemimpinan direktif $\left(\mathrm{X}_{2}\right)$ Secara Parsial Terhadap Kinerja Pegawai (Y)}

Hasil olahan data diperoleh nilai $t_{\text {hitung }}$ untuk variabel kepemimpinan direktif 1,117 lebih kecil dibandingkan dengan $t_{\text {tabel }}$ 1,674 dan nilai signifikan sebesar 0,269 (> 0.05) artinya tidak signifikan. Jadi terbukti bahwa kepemimpinan direktifsecara parsial 
berpengaruh tidak signifikan terhadap kinerja pegawai. Ditolak.

Hasil penelitian ini diperkuat (Yulistian et al., 2013)dan (Jumady, 2020a) gaya kepemimpinan direktif yaitu gaya kepemimpinan yang sering memberikan perintah atau tugas pada bawahannya serta membuat keputusan bagi dirinya sendiri. Pemimipin tipe kepemimpinan direktif ini menganggap kepemimpinannya merupakan hak pribadinya dan berpendapat bahwa pimpinan dapat menentukan apa saja dalam organisasi, tanpa mengadakan konsultasi dengan bawahanbawahannya yang melaksanakan.

\section{Pengaruh Kepemimpinan partisipatif} (X3) Secara Parsial Terhadap Kinerja Pegawai (Y)

Hasil olahan data diperoleh nilai $t_{\text {hitung }}$ untuk variabel kepemimpinan partisipatif 5,538lebih besar dibandingkan dengan $t_{\text {tabel }} 1,674$ dan nilai signifikan sebesar 0,001 $(<0.05)$ artinya signifikan. Jadi terbukti bahwa kepemimpinan partisipatifsecara parsial berpengaruh signifikan terhadap kinerja pegawai. Diterima.

Penelitian ini mendukung hasil penelitian yang dilakukan oleh (Putra et al., 2013), dan (Indah, 2019) menyatakan bahwa gaya kepemimpinan partisipatif berpengaruh terhadap kinerja pegawai. Hal ini berarti bahwa kepemimpinan partisipatif dapat memberikan pengaruh signifikan terhadap kinerja pegawai pada Kantor
Dinas Pendidikan dan Kebudayaan Kota Makassar, sehingga semakin tinggi tingkat gaya kepemimpinan partisipatif maka kinerja pegawai pada Kantor Dinas Pendidikan dan Kebudayaan kota Makassar akan semakin tinggi. Hal ini juga diperkuat (Hasibuan, 2014) kepemimpinan partisipatif memiliki kekuatan untuk memotivasi bawahannya, dengan meningkatnya motivasi kerja tersebut dan pemimpin melaksanakannya dengan persuasif maka akan terciptanya kerjasama yang serasi antara pemimpin dan bawahan, menumbuhkan loyalitas bawahan, dan yang terpenting yaitu mampu menumbuhkan kinerja bawahan.

\section{PENUTUP}

\section{SIMPULAN}

Berdasarkan hasil penelitian, maka ada beberapa kesimpulan sebagai berikut:

1. Secara simultan variabel gaya kepemimpinan suportif, direktif dan partisipatif berpengaruh positif terhadap kinerja pegawai.

2. Secara parsial kepemimpinan suportif berpengaruh positif dan signifikan terhadap kinerja pegawai, artinya ketika pimpinan memberikan banyak dukungan bawahan dalam menjalankan aktivitas sehari-hari di kantor baik yang bersifat materi maupun moril untuk menyelesaikan tugas yang diberikan.

3. Secara parsial kepemimpinan direktif berpengaruh positif dan tidak 
signifikan terhadap kinerja pegawai, artinya ketika pimpinan memberikan perintah yang tegas pada bawahannya maka pegawai akan segara melakukan perintah pimpinan tersebut

4. Secara parsial kepemimpinan partisipatif berpengaruh positif dan signifikan terhadap kinerja pegawai, artinya ketika pimpinan memberikan peluang pada bawahan untuk membuat keputusan dan masukan dalam setiap aktivitas untuk memberikan pelayanan public yang efektif dan efisien.

\section{SARAN}

Pemimpin hendaknya lebih memperhatikan gaya kepemimpinan yang dilakukan karena hal tersebut menggambarkan berpengaruh pada motivasi kerja yang kemudian berimbas pada kinerja karyawan yang mana pada akhirnya berpengaruh pada pencapaian tujuan perusahaan.

Hasil penelitian perlu dikembangkan lebih lanjut dengan peneliti gaya kepemimpinan yanglain atau menambah item-item variabel dari penelitian ini untuk dapat mengetahui apa sajayang dapat meningkatkan kinerja pegawai.

\section{DAFTAR PUSTAKA}

Dunggio, S. (2020). Pengaruh Budaya Organisasi Terhadap Kinerja Pegawai Di Kantor Camat Dungingi Kota Gorontalo.
PUBLIK: Jurnal Manajemen Sumber Daya Manusia, Administrasi Dan Pelayanan Publik, VII(1), 1-9.

Handayani, D. N. (2017). Pengaruh Kedisiplinan Pimpinan Terhadap Kinerja Pegawai Di Kantor Kelurahan Lompo Riaja Kabupaten Barru. PUBLIK: Jurnal Manajemen Sumber Daya Manusia, Administrasi Dan Pelayanan Publik, IV(2), 101110.

Hasibuan, M. S. . (2014). Manajemen Sumber Daya Manusia (Revisi). Bumi Aksara.

Indah, priastuti dwi. (2019). Pengaruh Gaya Kepemimpinan Direktif, Suportif, Dan Partisipatif Terhadap Kinerja Karyawan Pada Cv. Aneka Mitra Jaya, Tangerang Selatan". Journal of Chemical Information and Modeling, 53(9), 1689-1699.

Jannah, A. S. R., \& Jumady, E. (2020). Efek Pemberian Insentif Dan Komitmen Dalam Upaya Peningkatan Produktivitas Kerja Karyawan PT Gelael Supermarket Makassar.AL-KALAM Jurnal Komunikasi, Bisnis Dan Manajemen, 7(2), 83-94.

Jumady, E. (2020a). Implementation of Total Quality Management and Leadership on Islamic Banking Financial Performance. ATESTASI: Jurnal Ilmiah Akuntansi, 3(2). 
Jumady, E. (2020b). Peran Moderasi Disiplin Kerja Pada Pengaruh Kepemimpinan Terhadap Produktivitas Kerja Karyawan Perbankan Syariah Di Makassar. Islamic Banking: Jurnal Pemikiran Dan Pengembangan Perbankan Syariah, 5(2), 1-20. https://doi.org/10.36908/isbank.v5 i2.110

Khairizah, A., Noor, I., \& Suprapto, A. (2015). Pengaruh gaya kepemimpinan terhadap kinerja karyawan (studi pada karyawan di Perpustakaan Universitas Brawijaya Malang). Jurnal Administrasi Publik (JAP), 3(7), 1268-1272.

Luthans, F. (2011). Perilaku Organisasi. Penerbit Andi.

Mathis, R. L., \& Jackson, J. H. (2011). Human resource Management (edisi 10). Penerbit Salemba Empat.

Putra, C. B., Utami, hamidah N., \& Hakam, M. S. (2013). Pengaruh Gaya Kepemimpinan Direktif, Suportif, Dan Partisipatif Terhadap Kinerja Karyawan (Studi Pada PT. Astra Internasional Tbk. Daihatsu Malang). Jurnal Administrasi Bisnis (JAB), 2(2), 11-20.

Rapanna, P., \& Jumady, E. (2020). The Impact of Corona Virus Outbreak Regarding the Large-Scale Social Restriction Policy on Economic Attitudes in Makassar.
International Journal of Social Science Studies, 8(5), 83. https://doi.org/10.11114/ijsss.v8i5 .4963

Robbins, S. P. (2015). Perilaku Organisasi. Penerbit Salemba Empat.

Sugiono. (2010). Metode penelitian Kuantitatif Kualitatif dan $R \& D$. CV. Alfabeta Bandung.

Tueno, N. S. (2016). Pengaruh Kepemimpinan Terhadap Motivasi Kerjas Pegawai Pada Dinas Tata Kota dan Pertamanan Kota Gorontalo. PUBLIK: Jurnal Manajemen Sumber Daya Manusia, Administrasi Dan Pelayanan Publik, III(2), 68-76.

Yulistian, A. S., Astuti, E. S., \& Utami, H. N. (2013). Pengaruh gaya kepemimpinan direktif, suportif, dan orientasi prestasi terhadap semangat kerja karyawan. Jurnal Administrasi Bisnis, 5(2), 1-7.

Zehir, C., Ertosun, Ö. G., Zehir, S., \& Müceldili, B. (2011). The effects of leadership styles and organizational culture over firm performance: Multi-national companies in istanbul. Procedia Social and Behavioral Sciences, 24, 1460-1474. https://doi.org/10.1016/j.sbspro.20 11.09.032 